\title{
Circulating tumor cells before and during follow-up after breast cancer surgery
}

\author{
GUUS VAN DALUM ${ }^{1}$, GERT JAN VAN DER STAM ${ }^{1}$, ARJAN G.J. TIBBE ${ }^{1}$, BAS FRANKEN ${ }^{2}$, \\ WALTER J.B. MASTBOOM ${ }^{2}$, IVAN VERMES ${ }^{3}$, MARCO R. DE GROOT ${ }^{3}$ and LEON W.M.M. TERSTAPPEN ${ }^{1}$ \\ ${ }^{1}$ Medical Cell BioPhysics Group, MIRA Institute, University of Twente, Enschede; \\ Departments of ${ }^{2}$ Surgery and ${ }^{3}$ Internal Medicine, Medisch Spectrum Twente, Enschede, The Netherlands
}

Received June 12, 2014; Accepted July 30, 2014

DOI: 10.3892/ijo.2014.2694

\begin{abstract}
The presence of circulating tumor cells (CTC) is an independent prognostic factor for progression-free and overall survival for patients with metastatic and newly diagnosed breast cancer. The present study was undertaken to explore whether the presence of CTC before and during follow-up after surgery is associated with recurrence free survival (RFS) and overall survival (OS). In a prospective single center study, CTC were enumerated with the CellSearch system in $30 \mathrm{ml}$ of peripheral blood of 403 stage I-III patients before undergoing surgery for breast cancer (A) and if available 1 week after surgery (B), after adjuvant chemo- and/or radiotherapy or before start of long-term hormonal therapy (C), one (D), two (E) and three (F) years after surgery. Patients were stratified into unfavorable $(\mathrm{CTC} \geq 1)$ and favorable $(\mathrm{CTC}=0)$ prognostic groups. $>1$ CTC in $30 \mathrm{ml}$ blood was detected in 75/403 (19\%) at $\mathrm{A}, 66 / 367(18 \%)$ at $\mathrm{B}, 40 / 263(15 \%)$ at $\mathrm{C}, 30 / 235(12 \%)$ at D, 18/144 (11\%) at E and 11/83 (13\%) at F. RFS and OS was significantly lower for unfavorable CTC as compared to favorable CTC before surgery $(\mathrm{P}=0.022$ and $\mathrm{P}=0.006)$, after adjuvant therapy $(\mathrm{P}<0.001$ and $\mathrm{P}=0.018)$ and one $(\mathrm{P}=0.006$ and $\mathrm{P}=0.013)$ and two $(\mathrm{P}<0.001$ and $\mathrm{P}=0.045)$ years after surgery, but not 1 week post-surgery. The presence of CTC in blood drawn pre and one and two years after surgery, but not post-surgery is associated with shorter RFS and OS for stage I-III breast cancer.
\end{abstract}

\section{Introduction}

Patients with non-metastatic breast cancer are treated surgically. Adjuvant treatment is indicated if the risk for recurrence

Correspondence to: Professor Leon W.M.M. Terstappen, Department of Medical Cell BioPhysics, MIRA Institute, University of Twente, Carre, Room C4437, Hallenweg 23, 7522 NH, Enschede, The Netherlands

E-mail: 1.w.m.m.terstappen@utwente.nl

Key words: circulating tumor cells, breast cancer, breast cancer related death, progression-free survival can be significantly reduced. Risk assessment is, thus, of utmost importance and is being conducted by means of TNM-classification and differentiation grade complemented by estrogen and progesterone receptor status, Her2neu expression and peri-tumor vascular invasion (1-5). More recent improvement of the risk assessment is obtained through the molecular characterization of the tumor (6-11). These methods identify genetic phenotypes with a higher likelihood for micrometastasis that can lead to disease recurrence. Detection of the actual presence of tumor cells beyond the primary tumor is preferred, but may not be sufficient, as one cannot distinguish between dormant tumor cells and those giving rise to recurrence of the disease $(12,13)$. The presence of micrometastases in bone marrow of breast cancer patients is associated with an increased risk for disease recurrence and death, but has not been adapted in standard clinical practice (14-16). A more attractive approach for the detection of the presence of tumor cells beyond the primary tumor is the detection of circulating tumor cells (CTC). For CTC detection a validated method is available (17) and several studies have demonstrated that the presence of CTC in patients with metastatic breast cancer is associated with a significantly shorter progression free and overall survival (18-21). In these studies CTC can be found in $7.5 \mathrm{ml}$ of blood in $\sim 70 \%$ of metastatic breast cancer patients. The presence of CTC in the non-metastatic setting is considerable lower and is similar to that found in patients with benign breast disease (22). Still a relation between their presence and an increased risk of disease recurrence has been shown in several studies (23-27). Whether or not this relation also exists when blood is investigated for the presence of tumor cells after surgical removal of the tumor and during follow-up has not yet been investigated. In a previous study we investigated the relation between the presence of CTC before breast cancer surgery and recurrence free survival and breast cancer related survival (22) and in the present study we report the relation between CTC in blood of these patients at several time-points after surgery and extended the follow-up of to a median of 5.7 years.

\section{Materials and methods}

Study design. Four hundred and three patients with stage I-III breast cancer were enrolled before surgery with curative intend in this prospective study between September 2003 and 
January 2009. The test result was not communicated to the treating physician and thus could not influence the further therapeutic algorithm. Blood $(30 \mathrm{ml})$ was drawn from all patients into four CellSave Preservative tubes (Veridex LLC, Raritan, NJ, USA) before surgery (A-Draw), a median of 1 week after surgery (B-Draw), after completion of adjuvant chemo- and/or radiotherapy or before start of long-term hormonal therapy (C-Draw), one (D-Draw), two (E-Draw) and three (F-Draw) years after surgery to measure CTC. All patients were treated in accordance with the Dutch national guidelines (28). The ethics board of Medisch Spectrum Twente (Enschede, The Netherlands) approved the study protocol and all patients provided informed consent. The primary endpoint of the present study was an association between the presence of CTC and breast cancer related recurrence and was reported earlier (22). In the present study, we report the relation between the presence of CTC and recurrence free and overall survival before and at several time-points after surgery. All patient records were reviewed in 2013 and updated for occurrence of breast related disease recurrence and death resulting in a follow-up period of 0.5-9.9 years (median 5.7)

CellSearch system. The CellSearch system (Veridex) was used to measure CTC. Four 7.5-ml aliquots of each patient were analyzed within $72 \mathrm{~h}$ after blood draw. This system immunomagnetically enriches CTC from $7.5 \mathrm{ml}$ of blood targeting the epithelial cell adhesion molecules (EpCAM). The enriched cells are labeled with the nucleic acid dye 4',6-diaminodino2-phenylindole (DAPI) and antibodies specific for leukocytes (CD45) labeled with allophycocyan (APC) and specific for epithelial cells (cytokeratin 8, 18 and 19) labeled with phycoerythrin (PE). Images of CTC candidates were captured by a semi-automatic magnetic fluorescence microscope and presented to experienced operators for classification as CTC when the cells were $>4 \mu \mathrm{m}$, expressed cytokeratin and lacked CD45 (17). The operators were blinded to the clinical status of the patient.

Statistical analysis. Two databases were created, one with the results of the CTC analysis, patient ID and inclusion date and one with the clinical data from the patient charts both were merged at the time of the analysis at the hospital. The following clinical data were included: age, menopausal status, tumor stage on basis of TNM classification, estrogen/progesterone receptor status, Her2Neu receptor status, differential grade of the tumor based on the Bloom-Richardson method, adjuvant treatment, date of recurrence if occurred, location of recurrence (local vs. distant), date of breast cancer associated death or non-breast cancer associated death. ER and PR positivity was defined at $10 \%$ or more. Her2Neu positivity was defined as $3+$ or $2+$ with confirmation. The time until recurrence was defined as the time between date of inclusion and the date on which the recurrence was confirmed with an appropriate diagnostic test. Follow-up time was defined as the time between inclusion date and the date of the last check-up. Patients with no objectified recurrence at the end of follow-up were considered free of recurrence. Statistical analysis was done using the SPSS version 20.0 (IBM, Armonk, NY, USA) an $\mathrm{R}(29)$. A P-value $<0.05$ was considered to indicate a significant difference. All tests were two-sided. Patients were divided into two groups: those without any CTC, and those with at least one CTC. Between-group differences in categorical variables were tested by the Pearson's Chi-squared test and in case of small numbers the Fisher's exact test. For between group differences in continues variables the Mann-Whitney U was performed. All significant univariate prognostic factors where included in a multivariate Cox proportional regression model. Interdependent covariates where removed from the multivariate model using stepwise elimination, using $\mathrm{P}>0.10$ as criteria. Kaplan-Meier curves for disease free survival, cancer related death and overall survival were generated and compared using the log-rank test.

\section{Results}

Patient characteristics and relation to recurrence and survival. Between September 2003 and January 2009, 403 patients with stage I-III breast cancer were included into the present study. Their age ranged from 29-90 years (mean and median of 59). Recurrence of disease was observed in 57 of $403(14.4 \%)$ patients, $43(10.7 \%)$ patients died of causes related to breast cancer and $57(14.1 \%)$ patients died of breast cancer or other causes. Patient characteristics and whether or not a significant relation was present between the presence of CTC, RFS and OS is shown in Table I.

Prevalence of CTC. The prevalence of CTC in the patients before and at several time-points after surgery is shown in Table II. In 75 out of the 403 patients (19\%) CTC were detected before surgery. At the time-points after surgery this frequency slowly decreased to $18,15,12,11$ and $13 \%$, respectively.

Association between presence of CTC before surgery, disease recurrence and survival. A total of 57 (14.4\%) patients developed disease recurrence and $43(10.7 \%)$ patients died during follow-up. Of the 75 patients with CTC before surgery, 17 (22.7\%) developed a recurrence compared to 40 of $328(12.2 \%)$ patients without CTC $(\mathrm{P}=0.019)$. Of the 75 patients with CTC before surgery, $19(25.3 \%)$ died compared to 39 of $328(11.9 \%)$ patients without CTC ( $\mathrm{P}=0.003)$. Kaplan-Meier plots for RFS and OS for patients with and without CTC before surgery in Fig. 1 show a significant difference in $\operatorname{RFS}(\mathrm{P}=0.022)$ and $\mathrm{OS}$ $(\mathrm{P}=0.006)$ indicating that the presence of $\mathrm{CTC}$ is a negative prognostic indicator.

Association between presence of CTC at several time intervals after surgery, disease recurrence and survival. Blood was drawn in 367 of the 403 (93\%) of patients a median of 1 week after surgery. Although the proportion of patients with CTC was similar (19 vs. 18\%) no significant associated was found between the presence of CTC and RFS and OS (Table III). To investigate whether this was due to the difference in the number of patients with blood drawn after surgery the same analysis was done for the blood drawn of these 367 patients taken before surgery and is shown in italics in Table III. This clearly shows that the presence of CTC in the same group of patients is highly significant in the blood drawn before, but not after surgery. After completion of adjuvant therapy blood was drawn in 263 of the 348 patients that received adjuvant therapy. Presence of CTC was significantly associated with 
Table I. Characteristics of the 403 patients and their relation to recurrence free survival (RFS) and breast cancer related death (BCRD).

\begin{tabular}{lrrr}
\hline & & & $\begin{array}{c}\% \\
\text { CTC } \geq\end{array}$ \\
Stage & & & \\
I & 178 & 44 & 16 \\
IIA & 122 & 30 & 18 \\
IIB & 52 & 12 & 17 \\
IIIA $^{\text {a }}$ & 40 & 10 & 31 \\
IIIB $^{\text {a }}$ & 9 & 2 & \\
IIIC $^{\text {a }}$ & 2 & 1 & \\
T stage $_{\text {T1 }}$ & & & \\
T2 $^{\text {T3 }}$ & 229 & 57 & 15 \\
T4 $^{\text {a }}$ & 154 & 38 & 22 \\
& 12 & 3 & 30 \\
& 8 & 2 &
\end{tabular}

$\mathrm{N}$ stage

$\begin{array}{lrrr}\text { N0 } & 261 & 65 & 18^{\mathrm{b}} \\ \text { N1 } & 98 & 25 & 12^{\mathrm{b}} \\ \text { N2 } & 42 & 10 & 34^{\mathrm{b}} \\ \text { N3 }^{\mathrm{a}} & 2 & 1 & \end{array}$

Histology

0.603

0.971

Lobular

$44 \quad 11$

23

Ductal

$341 \quad 84$

19

Other

$18 \quad 5$

Differentiation

I

II

$98 \quad 24$

$184 \quad 46$

$121 \quad 30$

III

ER

Positive

$341 \quad 85$

Negative

$62 \quad 15$

PR

Positive

$289 \quad 72$

Negative

$114 \quad 28$

Her2/neu

Positive

$$
81 \quad 20
$$$$
322 \quad 80
$$

Negative

Adjuvant chemotherapy

$\begin{array}{llll}\text { Yes } & 150 & 37 & 22 \\ \text { No } & 253 & 63 & 16\end{array}$

Adjuvant radiotherapy

$\begin{array}{llll}\text { Yes } & 295 & 73 & 17 \\ \text { No } & 108 & 27 & 22\end{array}$

$<0.001<0.001$

$0.017 \quad 0.002$
Table I. Continued.

\begin{tabular}{|c|c|c|c|c|c|}
\hline & $\mathrm{N}$ & $\%$ & $\begin{array}{c}\% \\
\mathrm{CTC} \geq 1\end{array}$ & $\begin{array}{c}\text { RFS } \\
\text { P-value }\end{array}$ & $\begin{array}{c}\text { OS } \\
\text { P-value }\end{array}$ \\
\hline $\begin{array}{l}\text { Adjuvant } \\
\text { hormonal therapy }\end{array}$ & & & & 0.193 & 0.282 \\
\hline Yes & 192 & 48 & $13^{\mathrm{b}}$ & & \\
\hline No & 211 & 53 & $24^{\mathrm{b}}$ & & \\
\hline \multicolumn{6}{|l|}{ Age } \\
\hline \multicolumn{6}{|l|}{ Continues } \\
\hline Menopausal status & & & & 0.441 & 0.183 \\
\hline Pre & 119 & 30 & 22 & & \\
\hline Post & 284 & 70 & 17 & & \\
\hline
\end{tabular}
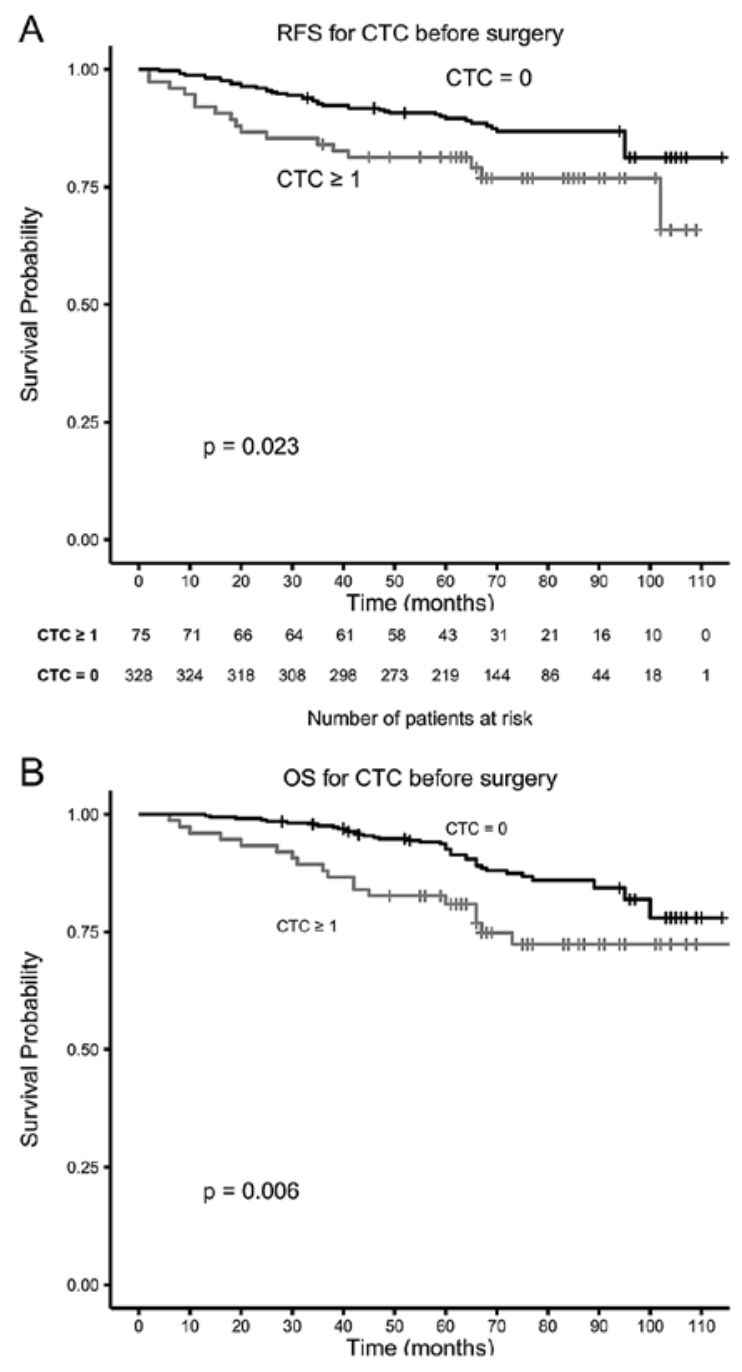

$\begin{array}{rrrrrrrrrrrrr}\text { CTC } \geq 1 & 75 & 73 & 71 & 69 & 65 & 61 & 47 & 33 & 22 & 16 & 10 & 1 \\ \text { CTC }=0 & 328 & 328 & 325 & 321 & 316 & 295 & 243 & 160 & 93 & 47 & 21 & 2\end{array}$

Number of patients at risk

Figure 1. Kaplan-Meier graphs of (A) recurrence free survival and (B) overall survival of breast cancer patients with $0 \mathrm{CTC} / 30 \mathrm{ml}$ and $>1 \mathrm{CTC} / 30 \mathrm{ml}$ of blood before surgical intervention. 
Table II. Prevalence of circulating tumor cells before surgery and at several time points after surgery.

\begin{tabular}{|c|c|c|c|c|c|c|}
\hline & $\begin{array}{l}\text { (A) Before } \\
\text { surgery } \\
n=403\end{array}$ & $\begin{array}{c}\text { (B) After } \\
\text { surgery } \\
n=367\end{array}$ & $\begin{array}{l}\text { (C) After } \\
\text { adjuvant therapy } \\
n=263\end{array}$ & $\begin{array}{c}\text { (D) One year } \\
\text { after surgery } \\
n=235\end{array}$ & $\begin{array}{c}\text { (E) Two years } \\
\text { after surgery } \\
n=162\end{array}$ & $\begin{array}{c}\text { (F) Three years } \\
\text { after surgery } \\
n=83\end{array}$ \\
\hline CTC & $\mathrm{n}(\%)$ & $\mathrm{n}(\%)$ & $\mathrm{n}(\%)$ & $\mathrm{n}(\%)$ & $\mathrm{n}(\%)$ & $\mathrm{n}(\%)$ \\
\hline 0 & $328(81)$ & $301(82)$ & $223(85)$ & $215(88)$ & 144 (89) & $72(87)$ \\
\hline$\geq 1$ & 75 (19) & $66(18)$ & $40(15)$ & 30 (12) & $18(11)$ & $11(13)$ \\
\hline 1 & $48(12)$ & $33(9)$ & $31(12)$ & $21(9)$ & $13(8)$ & $9(11)$ \\
\hline 2 & $4(1)$ & $12(3)$ & $6(2)$ & $4(2)$ & $2(1)$ & $0(0)$ \\
\hline 3 & $6(2)$ & $8(2)$ & $0(0)$ & $0(0)$ & $0(0)$ & $1(1)$ \\
\hline 4 & $5(1)$ & $4(1)$ & $0(0)$ & $1(0)$ & $0(0)$ & $0(0)$ \\
\hline$>4$ & $12(3)$ & $9(3)$ & $3(1)$ & $4(2)$ & $3(3)$ & $1(1)$ \\
\hline
\end{tabular}

${ }^{\text {a }}$ ong-term hormonal therapy is not included in the adjuvant therapy.

Table III. Relation between the presence of CTC and recurrence free survival (RFS) or overall survival (OS).

\begin{tabular}{|c|c|c|c|c|}
\hline & $\mathrm{N}$ & $\begin{array}{c}\text { Unfavorable } \\
(\%)\end{array}$ & $\begin{array}{c}\text { RFS } \\
\text { P-value }\end{array}$ & $\begin{array}{c}\text { OS } \\
\text { P-value }\end{array}$ \\
\hline Before surgery & 403 & 19 & 0.022 & 0.006 \\
\hline $\begin{array}{l}\text { After surgery } \\
\text { (before surgery draw) }\end{array}$ & 367 & $\begin{array}{l}18 \\
19\end{array}$ & $\begin{array}{l}0.852 \\
0.006\end{array}$ & $\begin{array}{l}0.182 \\
0.005\end{array}$ \\
\hline $\begin{array}{l}\text { After adjuvant TX } \\
\text { (before surgery draw) }\end{array}$ & 263 & $\begin{array}{l}15 \\
17\end{array}$ & $\begin{array}{r}<0.001 \\
0.026\end{array}$ & $\begin{array}{l}0.018 \\
0.013\end{array}$ \\
\hline $\begin{array}{l}\text { After } 1 \text { year } \\
\text { (before surgery draw) }\end{array}$ & 245 & $\begin{array}{l}12 \\
16\end{array}$ & $\begin{array}{l}0.006 \\
0.672\end{array}$ & $\begin{array}{l}0.013 \\
0.320\end{array}$ \\
\hline $\begin{array}{l}\text { After } 2 \text { years } \\
\text { (before surgery draw) }\end{array}$ & 162 & $\begin{array}{l}11 \\
23\end{array}$ & $\begin{array}{r}<0.001 \\
0.720\end{array}$ & $\begin{array}{l}0.045 \\
0.275\end{array}$ \\
\hline $\begin{array}{l}\text { After } 3 \text { years } \\
\text { (before surgery draw) }\end{array}$ & 83 & $\begin{array}{l}13 \\
27\end{array}$ & $\begin{array}{l}0.439 \\
0.591\end{array}$ & $\begin{array}{l}0.056 \\
0.787\end{array}$ \\
\hline
\end{tabular}

For each time-point during follow-up (FU) the recurrence free survival (RFS) and overall survival (OS) for this subset of patients was also calculated from the before surgery draw analysis (shown in italics).

RFS and OS (Table III). Presence of CTC in blood drawn 1 year $(n=245)$ and 2 years $(n=162)$ after surgery was also significantly associated with RFS and OS (Table III). This significant difference was not reached in the same group of patients when considering the CTC in the blood drawn presurgery. The presence of CTC in 83 patients with blood drawn 3 years after surgery was not significantly associated with RFS and OS (Table III). Fig. 2 shows the Kaplan-Meier plots for OS for patients with and without CTC after surgery (Fig. 2A), 1 year after surgery (Fig. 2B), 2 years after surgery and 3 years after surgery (Fig. 2D).

Multivariate analysis for disease recurrence and survival. Multivariate logistic regression analysis was performed to identify the parameters most significant for RFS and OS of breast cancer patients. For this the univariate significant parameters for RFS and OS were used. Table IV shows this analysis in which conditionally stepwise elimination of least significant parameters was applied for recurrence RFS and OS.

\section{Discussion}

Several studies have shown that the presence of tumor cells in blood of breast cancer patients before surgery $(22,24,25,27)$ and with metastatic disease (18-20) is associated with poor outcome. To simplify the interpretation of the CTC results patients with metastatic disease are subdivided into those with favorable CTC ( $<5 / 7.5 \mathrm{ml}$ of blood) and those with unfavorable CTC ( $>5 / 7.5 \mathrm{ml}$ of blood) (18). In actuality, the peripheral blood circulating tumor cell load reflects the prognosis of the patient and the larger the CTC load the lower the survival time $(30,31)$. By fitting the distribution of the CTC frequency in patients with metastatic disease in whom CTC were detected it was calculated that a 10 -fold increase in CTC corresponds to a decrease in survival of 6.6 month and suggested that this trend continues at CTC concentrations that cannot be detected with current technology (31). Efforts are ongoing to determine whether CTC indeed can be identified in all patients with metastatic carcinomas by probing larger blood volumes for the presence of CTC $(32,33)$. To detect a breast cancer tumor before the disease is disseminated using circulating tumor cells will be even more challenging (34). One of the largest difficulties is the discrimination between those tumor cells that can cause harm and those that may remain dormant. This is exemplified by the presence of micro-metastasis in the bone marrow in $\sim 30 \%$ of patients at the time of diagnosis, but although their presence is associated with an increased risk for disease recurrence not all of the patients with micrometastasis will develop a disease recurrence $(15,16)$. Likewise, not all patients in which CTC are detected before surgery will develop a disease recurrence $(22,25,35)$. Aneusomie of CTC has been demonstrated in patients suspect for dormant breast cancer suggesting that at least some of these cells are indeed 
Table IV. Multivariate Cox proportional hazard regression analysis of univariate significant parameters with a conditional stepwise elimination of the least significant for recurrence free survival (RFS) and overall survival (OS).

\begin{tabular}{|c|c|c|c|c|c|}
\hline & Variables & Categories & P-value & Hazard ratio & $95 \% \mathrm{CI}$ \\
\hline \multirow[t]{6}{*}{ RFS } & CTC & Negative vs. positive & 0.057 & 1.96 & $0.98-3.17$ \\
\hline & Her2Neu & Negative vs. positive & 0.039 & 1.82 & $1.03-3.20$ \\
\hline & Differentiation & I vs. II & 0.157 & 2.02 & $0.76-5.38$ \\
\hline & Differentiation & I vs. III & 0.017 & 3.38 & $1.25-9.15$ \\
\hline & N-stage & N0 vs. N1 & 0.023 & 2.04 & $1.10-3.76$ \\
\hline & $\mathrm{N}$-stage & N0 vs. N2 and N3 & 0.028 & 2.17 & $1.09-4.34$ \\
\hline \multirow[t]{9}{*}{ OS } & Age & & $<0.001$ & 1.05 & $1.03-1.08$ \\
\hline & CTC & Negative vs. positive & 0.002 & 2.60 & $1.43-4.72$ \\
\hline & ER & Negative vs. positive & 0.003 & 0.36 & $0.19-0.71$ \\
\hline & Differentiation & I vs. II & 0.423 & 1.46 & $0.58-3.68$ \\
\hline & Differentiation & I vs. III & 0.021 & 3.06 & $1.18-7.90$ \\
\hline & $\mathrm{N}$-stage & N0 vs. N1 & $<0.001$ & 3.14 & $1.69-5.84$ \\
\hline & $\mathrm{N}$-stage & $\mathrm{N} 0$ vs. $\mathrm{N} 2$ and $\mathrm{N} 3$ & 0.050 & 2.20 & $1.00-4.85$ \\
\hline & T-stage & T1 vs. T2 & 0.595 & 1.17 & $0.66-2.08$ \\
\hline & T-stage & $\mathrm{T} 1 \mathrm{vs.T} 3$ and $\mathrm{T} 4$ & 0.016 & 3.00 & $1.23-7.33$ \\
\hline
\end{tabular}
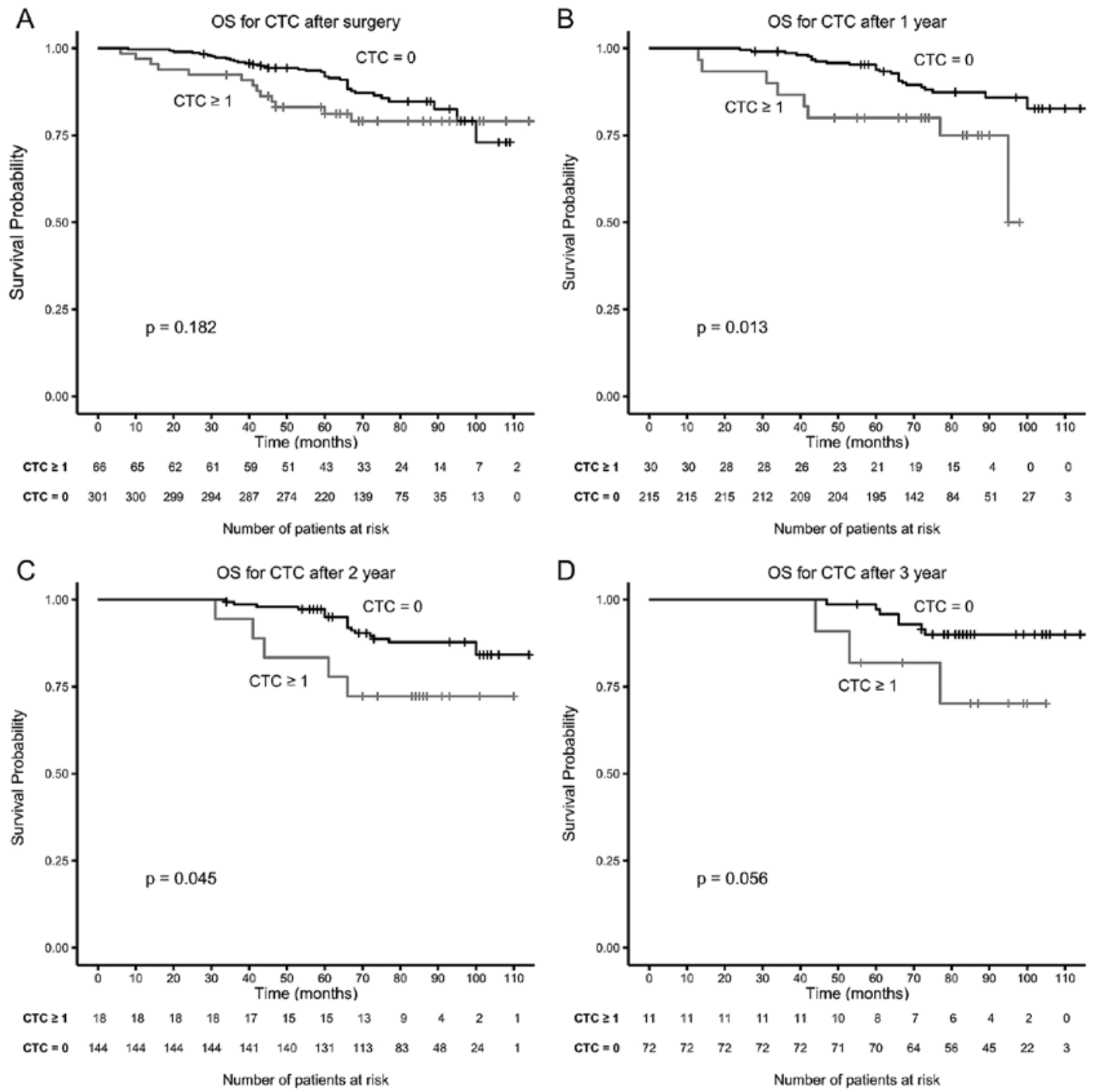

Figure 2. Kaplan-Meier graphs of overall survival of breast cancer patients with $0 \mathrm{CTC} / 30 \mathrm{ml}$ and $>1 \mathrm{CTC} / 30 \mathrm{ml}$ of blood (A) after surgery, (B) 1 year after surgery, (C) 2 years after surgery and (D) 3 years after surgery. 
tumor cells but in a dormant state (12). Furthermore, cells classified as CTC can also be detected at low frequency in patients with benign disease suggesting that they may not be tumor cells which can explain part of the absence of recurrence in CTC positive patients with cancer (22).

In the present study, we investigated the presence of CTC in $30 \mathrm{ml}$ of blood before and during follow-up after surgery to determine whether CTC could be detected and whether or not their presence after surgery was still related to poor outcome. Results of the pre-surgery blood were presented before (22), but here we extended the follow-up and investigated the role of CTC in blood drawn during 3 years of follow-up. The longer follow-up increased the significance of the presence of CTC and CTC are highly significant in multivariate analysis for OS. The proportion of patients with CTC detected before surgery (19\%) was not different in the weeks after surgery (18\%). Surprisingly, CTC presence was highly significant for RFS ( $\mathrm{P}=0.022)$ and $\mathrm{OS}(\mathrm{P}=0.006)$ in blood draw pre-surgery, but not in the post-surgery blood for RFS $(\mathrm{P}=0.852)$ and $\mathrm{OS}$ $(\mathrm{P}=0.182)$. Possible explanations are that the cells detected in the post-surgery blood are epithelial cells or tumor cells with no metastatic potential shed during surgery. Alternatively, these cells are similar to those observed in patients with benign disease (22). Remarkably, the same phenomenon is observed in patients undergoing surgery for colorectal cancer (36).

Presence of CTC in blood drawn after adjuvant therapy, but before starting long-term hormonal therapy was highly significant for both RFS $(\mathrm{P}<0.001)$ and OS $(\mathrm{P}=0.018)$. This may not be surprising as this patient group already has a higher risk for disease recurrence as compared to those not receiving adjuvant. This significance was, however, also observed in the patient group comprising patients that did not receive adjuvant therapy as the presence of CTC was significant for RFS and OS in blood drawn one and two years after surgery. Remarkably, CTC in blood of the same patients drawn before surgery was not significant. These results indeed indicate a potential important role for the monitoring of patients treated for breast cancer, but also highlight that improvement of CTC technology is needed before it can play a role in clinical practice. Relative simple improvement in CTC technology can be obtained by automation of the assignment of objects as CTC and optimization of the definition by which the human error and subjectivity can be eliminated (37). Further needed is confirmation at the genetic level that the cells identified as CTC are indeed tumor cells. Technology to detect genetic abnormalities associated with cancer in CTC is indeed feasible $(12,33,38-43)$ but will need to be implemented in this setting. Still remaining is the challenge to discriminate between those tumor cells signifying impeding relapse and those that do not (44). Availability of larger numbers of CTC will help to address these questions and be obtained by probing larger blood volumes for the presence of CTC $(30,33,34)$ and alternative phenotypes $(45,46)$ or physical characteristics (47-49).

In conclusion, CTC found in the blood at several time-points after surgery for breast cancer extends our knowledge to what already has been shown for CTC detection before surgery, it is also associated with a shorter RFS and OS. However, improvement in the determination and characterization of CTC is necessary in order to design randomized trials guiding the effect of the adjuvant therapy or starting pre-emptive therapy in those patients with presence of CTC after surgery.

\section{Acknowledgements}

The present study was supported by the Immunicon Corporation responsible for the development of the CellSearch system.

\section{References}

1. Parkin DM, Bray F, Ferlay J and Pisani P: Global cancer statistics, 2002. CA Cancer J Clin 55: 74-108, 2005.

2. Boyages J, Chua B, Taylor R, Bilous M, Salisbury E, Wilcken N and Ung O: Use of the St Gallen classification for patients with node-negative breast cancer may lead to overuse of adjuvant chemotherapy. Br J Surg 89: 789-796, 2002.

3. Colomer R, Viñas G, Beltran M, et al: Validation of the 2001 St Gallen risk categories for node-negative breast cancer using a database from the Spanish Breast Cancer Research Group (GEICAM). J Clin Oncol 22: 961-962, 2004.

4. Lundin J, Lehtimäki T, Lundin M, et al: Generalisability of survival estimates for patients with breast cancer--a comparison across two population-based series. Eur J Cancer 42: 3228-3235, 2006.

5. Olivotto IA, Bajdik CD, Ravdin PM, et al: Population-based validation of the prognostic model ADJUVANT! for early breast cancer. J Clin Oncol 23: 2716-2725, 2005.

6. Cronin M, Pho M, Dutta D, et al: Measurement of gene expression in archival paraffin-embedded tissues: development and performance of a 92-gene reverse transcriptase-polymerase chain reaction assay. Am J Pathol 164: 35-42, 2004.

7. Sørlie T, Perou CM, Tibshirani R, et al: Gene expression patterns of breast carcinomas distinguish tumor subclasses with clinical implications. Proc Natl Acad Sci USA 98: 10869-10874, 2001.

8. Perou CM, Sørlie T, Eisen MB, et al: Molecular portraits of human breast tumours. Nature 406: 747-752, 2000.

9. Wang Y, Klijn JGM, Zhang Y, et al: Gene-expression profiles to predict distant metastasis of lymph-node-negative primary breast cancer. Lancet 365: 671-679, 2005.

10. West M, Blanchette C, Dressman H, et al: Predicting the clinical status of human breast cancer by using gene expression profiles. Proc Natl Acad Sci USA 98: 11462-11467, 2001.

11. Van 't Veer LJ, Dai H, van de Vijver MJ, et al: Gene expression profiling predicts clinical outcome of breast cancer. Nature 415: 530-536, 2002.

12. Meng S, Tripathy D, Frenkel EP, et al: Circulating tumor cells in patients with breast cancer dormancy. Clin Cancer Res 10: 8152-8162, 2004.

13. Vessella RL, Pantel K and Mohla S: Tumor cell dormancy: an NCI workshop report. Cancer Biol Ther 6: 1496-1504, 2007.

14. Fehm T, Braun S, Muller V, et al: A concept for the standardized detection of disseminated tumor cells in bone marrow from patients with primary breast cancer and its clinical implementation. Cancer 107: 885-892, 2006.

15. Braun S and Marth C: Circulating tumor cells in metastatic breast cancer - toward individualized treatment? N Engl J Med 351: 824-826, 2004.

16. Braun S, Vogl F and Naume B: A pooled analysis of bone marrow micrometastasis in breast cancer. N Engl J Med 353: 793-802 2005.

17. Allard WJ, Matera J, Miller MC, et al: Tumor cells circulate in the peripheral blood of all major carcinomas but not in healthy subjects or patients with nonmalignant diseases. Clin Cancer Res 10: 6897-6904, 2004.

18. Cristofanilli M and Budd G: Circulating tumor cells, disease progression, and survival in metastatic breast cancer. Engl J Med 351: 781-791, 2004.

19. Liu MC, Shields PG, Warren RD, et al: Circulating tumor cells: a useful predictor of treatment efficacy in metastatic breast cancer. J Clin Oncol 27: 5153-5159, 2009.

20. Pierga JY, Hajage D, Bachelot T, et al: High independent prognostic and predictive value of circulating tumor cells compared with serum tumor markers in a large prospective trial in first-line chemotherapy for metastatic breast cancer patients. Ann Oncol 23: 618-624, 2012. 
21. Bidard F, Peeters D and Fehm T: Clinical validity of circulating tumour cells in patients with metastatic breast cancer: a pooled analysis of individual patient data. Lancet Oncol 15: 406-414 2014.

22. Franken B, de Groot MR, Mastboom WJB, Vermes I, van der Palen J, Tibbe AGJ and Terstappen LWMM: Circulating tumor cells, disease recurrence and survival in newly diagnosed breast cancer. Breast Cancer Res 14: R133, 2012.

23. Mathiot C, Brain E, Delaloge S, Pierga J, Marty M, Giachetti S and de Cremoux P: Circulating tumor cell detection predicts early metastatic relapse after neoadjuvant chemotherapy in large operable and locally advanced breast cancer in a phase II randomized trial. Clin Cancer Res 14: 7004-7010, 2008.

24. Jueckstock JK, Rack BK, Zwingers T, Hepp PGM, Schneeweiss A Beckmann MW, Lichtenegger W, Sommer HL, Pantel K, Tesch H, Forstbauer H, Lorenz R, Rezai M, Neugebauer JK, Andergassen U, Friese K, et al: Prognostic relevance of circulating tumor cells (CTC) before adjuvant chemotherapy in patients with breast cancer: results of the German SUCCESS trial. J Clin Oncol 29 (Suppl): 1033, 2011.

25. Lucci A, Hall CS, Lodhi AK, et al: Circulating tumour cells in non-metastatic breast cancer: a prospective study. Lancet Oncol 13: 688-695, 2012.

26. Janni WJ, Rack BK, Terstappen LWMM, et al: A pooled analysis of the prognostic relevance of circulating tumor cells in early breast cancer. Cancer Res 73 (Suppl 24): PD6-6, 2013.

27. Bidard FC, Mathiot C, Delaloge S, et al: Single circulating tumor cell detection and overall survival in nonmetastatic breast cancer. Ann Oncol 21: 729-733, 2010.

28. National guidelines breast cancer (richlijn mamacarcinoom 2008). [http://www.cbo.nl].

29. R Core Team: R: A Language and Environment for Statistical Computing. Version 3.0.1 (2013-05-16).

30. Coumans FAW, Ligthart ST, Uhr JW and Terstappen LWMM: Challenges in the enumeration and phenotyping of CTC. Clin Cancer Res 18: 5711-5718, 2012.

31. Coumans FAW, Ligthart ST and Terstappen LWMM Interpretation of changes in circulating tumor cell counts. Transl Oncol 5: 486-491, 2012

32. Barradas AM and Terstappen LWMM: Towards the biological understanding of CTC: capture technologies, definitions and potential to create metastasis. Cancers (Basel) 5: 1619-1642, 2013.

33. Fischer JC, Niederacher D, Topp SA, et al: Diagnostic leukapheresis enables reliable detection of circulating tumor cells of nonmetastatic cancer patients. Proc Natl Acad Sci USA 110: 16580-16585, 2013.

34. Coumans FAW, Siesling S and Terstappen LWMM: Detection of cancer before distant metastasis. BMC Cancer 13: 283, 2013.

35. Pierga JY, Bidard FC, Mathiot C, et al: Circulating tumor cell detection predicts early metastatic relapse after neoadjuvant chemotherapy in large operable and locally advanced breast cancer in a phase II randomized trial. Clin Cancer Res 14: 7004, 2008.
36. Van Dalum G, de Groot M, Stam GJ, et al: Importance of circulating tumor cells in newly diagnosed colorectal cancer. In: Proc 105th Annual Meeting Amer Assoc for Cancer Res, San Diego, CA, abst 3064, 2014

37. Ligthart ST, Coumans FAW, Attard G, Cassidy AM, de Bono JS and Terstappen LWMM: Unbiased and automated identification of a circulating tumour cell definition that associates with overall survival. PLoS One 6: e27419, 2011.

38. Swennenhuis JF, Tibbe AGJ, Levink R, Sipkema RCJ and Terstappen LWMM: Characterization of circulating tumor cells by fluorescence in situ hybridization. Cytometry A 75: 520-527, 2009.

39. Swennenhuis JF, Reumers J, Thys K, Aerssens J and Terstappen LWMM: Efficiency of whole genome amplification of single circulating tumor cells enriched by CellSearch and sorted by FACS. Genome Med 5: 106, 2013.

40. Klein CA, Blankenstein TJF, Schmidt-Kittler O, Petronio M, Polzer B and Stoecklein NH: Mechanisms of disease Genetic heterogeneity of single disseminated tumour cells in minimal residual cancer. Lancet 360: 683-689, 2002.

41. Meng S, Tripathy D, Shete S, et al: uPAR and HER-2 gene status in individual breast cancer cells from blood and tissues. Proc Natl Acad Sci USA 103: 17361-17365, 2006.

42. Fehm T, Sagalowsky A, Clifford E, et al: Cytogenetic evidence that circulating epithelial cells in patients with carcinoma are malignant. Clin Cancer Res 8: 2073-2084, 2002.

43. Meng S, Tripathy D, Shete S, et al: HER-2 gene amplification can be acquired as breast cancer progresses. Proc Natl Acad Sci USA 101: 9393-9398, 2004

44. Uhr JW and Pantel K: Controversies in clinical cancer dormancy. Proc Natl Acad Sci USA 108: 12396-12400, 2011.

45. Sieuwerts AM, Kraan J, Bolt J, et al: Anti-epithelial cell adhesion molecule antibodies and the detection of circulating normal-like breast tumor cells. J Natl Cancer Inst 101: 61-66, 2009.

46. Mostert B, Kraan J, Sieuwerts AM, et al: CD49f-based selection of circulating tumor cells (CTCs) improves detection across breast cancer subtypes. Cancer Lett 319: 49-55, 2012.

47. Coumans FAW, van Dalum G, Beck M and Terstappen LWMM Filter characteristics influencing circulating tumor cell enrichment from whole blood. PLoS One 8: e61770, 2013.

48. Hou HW, Warkiani ME, Khoo BL, et al: Isolation and retrieval of circulating tumor cells using centrifugal forces. Sci Rep 3: $1259,2013$.

49. Vona G, Sabile A, Louha M, et al: Isolation by size of epithelial tumor cells: a new method for the immunomorphological and molecular characterization of circulatingtumor cells. Am J Pathol 156: 57-63, 2000. 